\title{
Does a workload influence the performance of bank employees?
}

\author{
Siswanto Siswanto ${ }^{a^{*}}$, Achmad Sani Supriyanto ${ }^{a}$, Ulfatun Ni’mah ${ }^{\text {a }}$, Nur Asnawi ${ }^{a}$ and Ismail \\ Suardi Wekke ${ }^{b}$
}

${ }^{a}$ Faculty of Economics, State Islamic University Of Maulana Malik Ibrahim Malang, Indonesia ${ }^{b}$ Sekolah Tinggi Agama Islam Negeri (STAIN) Sorong, Indonesia

\section{CHRON I CLE A B T T A C T}

\begin{tabular}{l} 
Article history: \\
Received: December 18, 2018 \\
Received in revised format: Feb- \\
ruary 12, 2019 \\
Accepted: February 18, 2019 \\
Available online: \\
February 18, 2019 \\
\hline Keywords: \\
Biographical characteristics \\
Employee performance \\
Motivation \\
Workload
\end{tabular}

\section{Introduction}

Employee performance is one of important work attitudes to examine and organizations often do a routine survey related to employee performance. The high performance of employees can increase customer loyalty and trust. Rabbanee et al. (2015) show that employee performance had significantly positive effects on customer's expected value, trust, and loyalty. Pang and Lu (2018) reported a substantial and positive effect of employees' motivation on financial figures such as return on asset and profitability. Moreover, employee may influence on the performance of non-financial dimensions including customer service, employee productivity, and customer satisfaction. The role of employee performance plays essential role for the development of organization. Thus, this study aims to investigate the determinants for improving the performance of bank employees. According to Jankingthong and Rurkkhum (2012) employee performance is an important variable, and it has long been examined in decades. In order to improve the employee performance, an analysis on employee performance determinant is necessary. Blitar and Nimah (2015) indicated that workload could be the determinant of employee performance and reported that the workload can improve the performance of bank employees, significantly, or the higher the workload, the greater the performance. Astianto (2014) reported positive implications of 
the workload variable on employee performance and demonstrated that when a workload increases, the performance of the employees will also increase. In other words, there was a positive correlation between the work load and the performance of the employees. The results of researches on the effect of workload on employee performance are still contradictory. Authors like Shah et al. (2011), Yao et al. (2011), Maurice (2013), Purnama (2014), Chielotam (2015), Mowlaei (2017), Albasu and Nyameh (2017), Maroofi et al. (2017), Kucukkocaoglu and Bozkurt (2018), Maldonado-Guzman et al. (2018) concluded that workload could improve the performance of employee based on metadata study associated with workload and employee performance. Moreover, according to these studies, the workload can improve the employee performance when its provision is in accordance with the potential and the employees' capabilities. Meanwhile, Bruggen (2015) found similar U share relationship between work load and employee performance. Likewise, the highest performance occurs when the workload is moderate. However, Johari et al. (2018) found different results and reported that the workload had no impact on the employees' performance. Researches by Sitepu et al. (2013) and Munawaroh et al. (2013) also indicate that a workload had no effect on employee performance.

Workload can increase work motivation, for instance, Sitepu (2013) in survey reported that workload positively affects the work motivation. Anita et al. (2013) reported the positive contribution of workload towards the improvement of work motivation and employee performance. The increase of workload can improve the spirit or employees' motivation. Meanwhile, Anigbogu and Nduka (2014), Rasheed, Humayon et al. (2016), Mosbah et al. (2017), Malarvizhi et al. (2018) and Le et al. (2018) reported that workload had no effect on motivation. The above results of empirical studies provide some evidence that research related to the implications of workload on employee performance through motivation is still contradictory, and there are some gaps to be filled. Employee performance also determines work motivation variable. Dewi and Wibawa (2016) confirmed the influence of motivation on employee performance, i.e. the higher the employees' motivation, the higher the performance. Some researchers provided some additional evidence on the positive effect of motivation on employee performance (Namvar et al., 2010). However, several other studies also show that employee performance is not influenced by motivation (Giovanni et al., 2015; Saranani, 2015; Santhi \& Gurunathan, 2014; Anyanwu et al., 2016; Jones Osasuyi \& Mwakipsile, 2017).

Shah et al. (2012) state that the performance of employees is a major concern for all type of business partners. To lead the business organization, high performance work system is known as distinguishing factor, however, many organizations are facing the issues of inadequate policies, managerial level low skills, and not permitting the employees to work with full potential.

\section{Employee Workload, Motivation, and Performance}

A performance of employee can be improved as long as workloads are maintained. A heavy workload can affect the physical and psychological condition of the employee (Nugraha et al., 2018). However, when the workload management is well-managed, it will positively influence on the performance. Workload also directly affects employee performance (Sitepu, 2013). The influence of workload on performance is also explained by Adityawarman et al. (2015) and Harras (2019) and Yurasti and Irfandi (2017). They stated that the performance of an employee could be improved through the provision of workload. An increase on motivation can improve the performance. Work motivation is a sensitive factor enhancing the performance, the higher the work motivation, the higher the performance (Kuranchie-Mensah \& Amponsah-Tawiah, 2016). Motivation means something encouraging someone to take a certain action. It can be a need or condition to cognitively and emotionally inspire an individual or employee, which would eventually reflect in an action or psychomotor. Based on that view, Kahn (2009) classified the theory of motivation into two, content and process theories. Some empirical studies show that motivation has an effect on employee performance. Habidin et al. (2013) believe that motivation can improve work motivation. It is also explained by Abrivianto (2014) that motivation affects employee performance. Workload can increase work motivation. A responsible employee will feel compelled to work 
well when given appropriate tasks related to his/her competence. Motivation can be improved by giving workload (Blitar \& Nimah, 2015). Ni'mah and Siswanto (2019) also provided that giving workload may increase employee's motivation. The results of the literature and empirical review prove that workload influence the motivation and employee performance variables. Employee performance variable is influenced by work motivation also affects employee performance.

Research study conducted by Bruggen (2015) examined the impact of work-related tasks on both qualitative and quantitative measure of employee's performance. To improve the capacity decision, it is very much significant to analyze the significance of different levels of the workload at work. Author explained the fact that literature context did not provide a clear evidence for the association between the two discussed issues and we need further empirical evidence. Through field data approach, his study collected 9210 observations from 27 employees working in a grocery supplier store through a period of more than three years. Based on the homogenous record of the employees, findings indicated that there was an inverted U-shape relationship between the performance of the employees and work load assigned by the business organization. He also explained that output of the employee increases up to a certain level, and the highest quality of performance was observed when the work load level was moderate. Their study utilized unique level of the data, which is not earlier collected in that specific shape. Study contributed towards the management literature and provided a significant evidence for empirical association between work load and employee performance.

Dasgupta (2013) investigated the volatility of the employees' workload within information technology industry and its impacts on motivation and performance and reported that when the employer understands the core reasons for the employees' motivation, there is an increase on the productivity. The factor of workload management was described some measures such as the structural type of workload and various demands of task by the employer where performance was considered the essential factors. In addition, quantitative factors cover the title of prioritize, diligence, availability of the time, and following of procedures defined to conduct a specific activity. He also explained that different causes could also be presented in the business to influence on the workload management.

Another study conducted by Lee and Way (2010) aimed to define the effect of workload of the employees and their effects on the performance. A sample of 40 housekeeping employees were finalized from Lorin Sentul hotel. They reported that there is a significant relationship between the workload and performance measures for the employees of the hotel industry. The effects of work-load on the performance in supply chain management systems have also studied by some other researches (Ali \& Haseeb, 2019; Haseeb et al., 2018; Haseeb et al., 2019; Suryanto et al., 2018). Duffield et al. (2011) conducted a study on nursing staff, workload, working environment and performance of the targeted industry through patient outcomes. They observed that increasing the level of the work load for the staff at hospital significantly and negatively affect the performance of the employees. Such negative performance is evaluated through medication errors and similar others. Chan and Lam (2011) analyzed the impact of work environment, related responsibilities to test the motivation and the employees' performance. They expressed that employee's empowerment was an internal marketing tool with the significant and positive influence on employees. A theoretical perspective was also applied to the workload mechanism while focusing on employee's performance. It is expressed that among various other indicators, performance appraisal was known to be a significant determinant of employees' work-related productivity and achievement of stated goals. Fritz and Sonnentag (2006) defined the fact that wellbeing along with recovery of the employees maintained a significant association with the performance/outcomes of the employees. For this purpose, the role of both vacation and workload was observed on the sample of 221 employees of a university. To collect the data, employees were targeted before and after one week of their vacations, along the defined level of work load by the university authorities. Findings of their study confirmed the fact that both factors of vacations and workload had their significant effect on the employee's outcome.

Another study conducted by Glaser et al. (1999), empirically examined the effect of workload on both performance and job stress while the effect of social support was evaluated as the main moderator. They 
developed two major hypotheses and empirically revisited where the first hypothesis examined the effect of stress between performance and workload while the second hypothesis examined the moderating effect of social support between workload and job stress. Findings of their study explained the fact that there was a significant relationship between the workload and performance of the employees. Meanwhile moderating effect of social support between employee's workload and their organizational outcome cannot be ignored. Some other studies have also provided theoretical and empirical contribution from the context of workload and performance (Alsuraykh et al. 2018; Avanzi et al., 2018; Baeriswyl et al., 2017; Gaillard, 2017; Ho, 2018; Huyghebaert et al., 2018; Miller et al., 2018; Prasad et al., 2018; Roster \& Ferrari, 2019). Based on these arguments, the researcher concludes with the following research hypotheses;

$\mathrm{H}_{1}$ : Work load has a significant positive effect on employee performance.

$\mathrm{H}_{2}$ : Work load has a significant positive effect on work motivation.

$\mathrm{H}_{3}$ : Work motivation has a significant positive effect on employee performance

\section{Research methods}

This research employs positivist paradigm with quantitative approach. Positivist paradigm refers to a deterministic philosophy, while the quantitative approach provides numerical description (Si, 2015). The samples of research are 74 employees. Some of them are working permanently, and some are on contract at state-owned banks in Blitar, East Java. Sampling technique uses random sampling method. Variables of workload and work motivation are used to analyze the level of influence on the working performance. Workload variables use indicators according to Norman et al. (2002) which include; physical load, mental load, and working time, while the employee performance variable is the actual achievement of employees compared with the expected performance of the employees. The employee performance variable applies indicators according to Khan and Jabbar (2013) which include; quality, quantity, and timeliness. Motivational variables use Maslow's motivational theory which includes physiological, safety, and social need as well as reward, and self-actualization. Data analysis uses path analysis. Path analysis is employed to analyze the relationship between independent and bound variables through mediator variables. Path analysis is used to test path analysis models. The model aims to determine the direct influence and indirect effect of a set of independent, intervening, and dependent variables. For the regression analysis, 10 items of work load factors under the title of regularly stressed at work, regulatory work above contract hours, working even at home, working at weekends, working with intense, hard work-related tasks, unrealized work pressure, non-cooperative work environment, extended workload, overall work load, ranging from WLF1 to WLF10 as well. For work performance, three items under the title of higher performance, comparatively to other employees, lower performance to other employees, and successful work-related achievements, ranging from Model1 to Model3, respectively. Overall robust regression technique is applied to examine the empirical facts of the study, through standard error and coefficients.

\section{Data analysis and discussion}

This study consists of 74 respondents who are bank employees in Blitar City. Table 1 shows the respondent's general description. Male respondents were the same as female respondents. It shows that 37 people $(50 \%)$ were male and 37 were female $(50 \%)$. Whereas, the characteristics of the respondents by age shows that $33.8 \%$ of respondents are aged less than 26 years. Respondents aged 26-30 years are 17 people (23\%), aged 31-35 years are as many as 4 people (5.4\%), and as many as 11 respondents (14.9\%) are aged over 40 years. The above data shows that the majority of respondents' age are less than 26 years. Employees younger than 26 years old have a motivation to grow. They are generations with high idealism and motivation to achieve. The samples used in this research are back and front officers. The following is the recapitulation description of respondents based on biographical characteristics. Table 1 shows that

front officers are fewer than the back ones. Front officers are amounted to 27 people (36.5\%), while back officers are 47 people (63.5\%). Back officers include human resources staff, junior staff, administration, secretary, backup clerk, and office boy. Front officers are tellers and customer service. The characteristics 
of respondents by employee status can be classified into permanent employees and those who are still on contract (temporary). The number of temporary respondents is amounted to 20 people $(27 \%)$, while the permanent ones are 54 people $(73 \%)$.

Table 1

Participants demographics

\begin{tabular}{|c|c|c|c|}
\hline Characteristics & Variable characteristics & Number & Percentage \\
\hline \multirow[t]{2}{*}{ Sex group } & Male & 37 & $50 \%$ \\
\hline & Female & 37 & $50 \%$ \\
\hline \multirow[t]{5}{*}{ Age group } & Less than 26 years old & 25 & $33.8 \%$ \\
\hline & $26-30$ & 17 & $23 \%$ \\
\hline & $31-35$ & 17 & $23 \%$ \\
\hline & $36-40$ & 4 & $5.4 \%$ \\
\hline & More than 40 years & 11 & $14.9 \%$ \\
\hline \multirow[t]{2}{*}{ Type of occupation } & Front office & 27 & $36.5 \%$ \\
\hline & Back office & 47 & $63.5 \%$ \\
\hline \multirow[t]{2}{*}{ Employee status } & Temporary & 20 & $27 \%$ \\
\hline & Permanent & 54 & $73 \%$ \\
\hline \multirow[t]{4}{*}{ Education } & Senior high school & 8 & $10.8 \%$ \\
\hline & Diploma & 3 & $4.0 \%$ \\
\hline & Undergraduate degree & 58 & $78.4 \%$ \\
\hline & Master & 5 & $6.8 \%$ \\
\hline \multirow[t]{5}{*}{ Salary/month (IDR) } & Less than $3,000,000$ & 14 & $19 \%$ \\
\hline & $3,000,000-4,000,000$ & 36 & $48.6 \%$ \\
\hline & $4,000,001-5,000,000$ & 12 & $16.2 \%$ \\
\hline & $5,000,001-6,000,000$ & 4 & $5.4 \%$ \\
\hline & More than 6.000 .000 & 8 & $10.8 \%$ \\
\hline \multirow[t]{5}{*}{ Length of employment } & Less than 5 years & 28 & $37.8 \%$ \\
\hline & $5-9$ years & 22 & $29.7 \%$ \\
\hline & $10-14$ years & 10 & $13.5 \%$ \\
\hline & $15-19$ years & 1 & $1.4 \%$ \\
\hline & More than 19 years & 13 & $17.6 \%$ \\
\hline
\end{tabular}

There are 8 respondents $(10.8 \%)$ of senior high school/equivalent graduates, 3 respondents $(4.1 \%)$ are diploma, $58(78.4 \%)$ bachelors, and $5(6.8 \%)$ masters. The majority of respondents are bachelors (78.4\%). Education level is an important biographical characteristics to determine job specifications.

The characteristics of respondents based on income level are explained below. Respondents with income level less than IDR 3,000,000 are as many as 14 people (19\%). Respondents with IDR 3,000,0014,000,000 income per month are 36 people (48.6\%). Those who earn IDR 4,000,001-5,000,000 per month are 8 people (10.8\%), while 12 respondents (16.2\%) have IDR 5,000,001-6,000,000 income per month. Furthermore, 4 respondents (5.4\%) earn more than IDR 6,000,000 per month. Respondents based on the length of employment are: 28 respondents $(37.8 \%)$ have been working for less than 5 years; $22(29.7 \%)$ of them have been working for 5 - 9 years; 10 (13.5\%) of them have been working for 10 - 14 years; 1 (1.4\%) respondents have been working for 15-19; and $13(17.6 \%)$ of them have been working for more than 19 years. Most employees in the current study work less than 5 years $(37.8 \%)$. This is common for the bank is a developing business. The implementation of the workload shows an average value of 3.26 , which is at the medium level, as shown in Table 2. Meanwhile, the implementation of motivation variable and employee performance is at high level. Variables of load and motivation have a significant correlation. The reliability test results of each variable indicate sufficient value in the workload variable (0.60), and high reliability in the variable motivation and employee performance.

Table 2

Means, Level of Implementations, Correlatioans, Reliabilities

\begin{tabular}{llccccc}
\hline & \multicolumn{1}{c}{ Variables } & Mean & Level of Implementation & 1 & 2 & 3 \\
\hline 1 & Workload & 3.26 & Medium & $(0.60)$ & & \\
2 & Motivation & 3.45 & High & $0.31 * *$ & $(0.86)$ & \\
3 & Employee performance & 3.63 & High & $0.39 * *$ & $0.44^{* *}$ & $(0.80)$ \\
\hline
\end{tabular}

Cronbach's alpha presented in parenthesis

$* * \mathrm{p}<0.01$

$* \mathrm{p}<0.05$ 
Path analysis in this study aims to analyze the influence of workload variable on performance. In addition, this study aims to determine the effect of workload on motivation, and the influence of motivation on employee performance. The influence of workload on motivation, which in the end effects on employee performance, can be seen in Table 3. The results of this study indicate that the workload had significant positive effect on employee performance. Likewise, motivation has a significant positive effect on employee performance. Workload also has a significant positive effect on motivation.

Table 3

Result of Analysis

\begin{tabular}{lccc}
\hline Variables & Coefficient $(\beta)$ & $\mathrm{T}_{\text {statistics }}$ & $\mathrm{P}_{\text {value }}$ \\
\hline Workload to employee performance & $0.28^{*}$ & 2.63 & 0.011 \\
Workload to motivation & $0.31^{* *}$ & 2.78 & 0.007 \\
Motivation to employee performance & $0.35^{* *}$ & 3.28 & 0.002 \\
\hline
\end{tabular}

** $\mathrm{p}<0.01$

$* \mathrm{p}<0.05$

The analysis describes a path analysis that shows the effect of workload on employee performance, as well as the influence of workload on the performance of bank employees through motivation variables. The following is the image of the path analysis model.

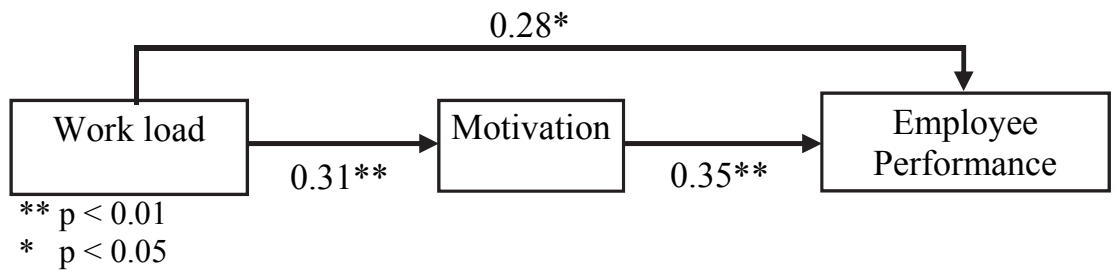

Fig. 1. Path analysis model

Fig. 1 shows the direct effect of workload on employee performance, and the indirect effect of workload on employee performance through motivation. The effect of workload on performance is 0.28 , with probability of $0.011(\mathrm{p}<0.05)$. It indicates that the increase of workload can directly improve employee performance. Workload can also increase work motivation $(\beta=0.31, p<0.01)$. Motivation variables can also improve employee performance $(\beta=0.35, \mathrm{p}<0.01)$. Workload directly affects employee performance. In addition, the workload also indirectly affects the performance with $0.1(0.312 \times 0.352)$. The total effect is 0.390 . The result of the total effect is greater than the direct one.

Table 4 depicts the findings for regression facts. Three factors for employee's performance under the title of "higher performance, comparatively to other employees" or Model1, "lower performance, comparatively to other employees" or Model 2, and work success through special achievement or Model 3 is observed for 10 items of work load factors or WLF. It is observed that first factor of work load is entitled as regulatory under stress during work has significant \& direct impact on lower performance of the employees. It indicates that higher level of work stressed leads to lower level of employee's performance in banking sector. For WLF2 (regulatory work above contract hours) reflects the fact that higher performance, comparatively to other employees in the bank is negatively and significantly affected. The factor of work load as entitled of "regularly working at home" has no significant influence on any of the performance factors of selected employees. Similarly, insignificant effect of WLF4 or working at weekends is observed for all the performance indicators of banking employees. Meanwhile, WLF measures the working with intense in the bank has shown significantly negative impact on both lower working, comparatively to other employees with the coefficient of $-.318 \&$ standard error of .0903 , and -.269 for success through higher achievements. It expresses that working with intense level has a negative impact on any type of work-related achievements by the employees. For hard work-related tasks or WLF6, effect 
on higher performance, comparatively to other employees has a significant relationship with the coefficient of -.323 and standard error of .151 respectively. For WLF7, the effect on lower performance of the employee has a positive and significant relationship. For WLF8, no significant impact on all the models is observed. In addition, the factor of extended workload has a negative but significant influence on higher performance as compared with other employees. It indicates that higher extended workload leads to an adverse effect on performance of the banking workers. For the factor of overall workload, the effect on higher employee performance is -.205 with the standard error of .107 , while the factor of successful achievements is negatively and significant associated with overall work load of the employees. The value of robust R-square for model 1 is .400, indicating overall change in higher performance of employees by all 10 indicators of workload factors. For model 2, the effect on model 2 is .201, expressing a lower impact. For model three, the effect is .226 on successful achievements by banking workers.

Table 4

Regression Findings for Workload factors and employee's performance

\begin{tabular}{|c|c|c|c|}
\hline VARIABLES & $\begin{array}{c}\text { (1) } \\
\text { Model } 1\end{array}$ & $\begin{array}{c}(2) \\
\text { Model } 2\end{array}$ & $\begin{array}{c}3) \\
\text { Model } 3\end{array}$ \\
\hline wlf1 (Regularly Stressed at work) & $\begin{array}{c}0.115 \\
(0.113)\end{array}$ & $\begin{array}{c}0.605 * * \\
(0.112)\end{array}$ & $\begin{array}{c}0.104 \\
(0.113)\end{array}$ \\
\hline wlf2 (Regularly work above contract hours) & $\begin{array}{c}-0.222^{*} \\
(0.116)\end{array}$ & $\begin{array}{c}0.140 \\
(0.116)\end{array}$ & $\begin{array}{l}0.0891 \\
(0.124)\end{array}$ \\
\hline wlf3 (working even at home) & $\begin{array}{c}0.140 \\
(0.0860)\end{array}$ & $\begin{array}{c}0.0855 \\
(0.0898)\end{array}$ & $\begin{array}{c}0.144 \\
(0.0950)\end{array}$ \\
\hline wlf4 (working at weekends) & $\begin{array}{c}0.0773 \\
(0.136)\end{array}$ & $\begin{array}{l}0.00247 \\
(0.0920)\end{array}$ & $\begin{array}{c}-0.128 \\
(0.118)\end{array}$ \\
\hline wlf5 (working with intense) & $\begin{array}{l}0.0630 \\
(0.115)\end{array}$ & $\begin{array}{c}-0.318 * * * \\
(0.0930)\end{array}$ & $\begin{array}{c}-0.269 * * \\
(0.112)\end{array}$ \\
\hline wlf6 (hard work-related tasks) & $\begin{array}{c}-0.323 * * \\
(0.151)\end{array}$ & $\begin{array}{l}0.0265 \\
(0.115)\end{array}$ & $\begin{array}{c}0.107 \\
(0.139)\end{array}$ \\
\hline wlf7 (unrealized work pressure) & $\begin{array}{c}0.225 \\
(0.135)\end{array}$ & $\begin{array}{l}0.229 * * \\
(0.0927)\end{array}$ & $\begin{array}{c}0.202 \\
(0.131)\end{array}$ \\
\hline wlf8 (non-cooperative work environment) & $\begin{array}{l}0.0619 \\
(0.128)\end{array}$ & $\begin{array}{l}0.0143 \\
(0.130)\end{array}$ & $\begin{array}{c}-0.154 \\
(0.119)\end{array}$ \\
\hline wlf9 (extended workload) & $\begin{array}{c}0.164 * \\
(0.0871)\end{array}$ & $\begin{array}{l}0.0587 \\
(0.111)\end{array}$ & $\begin{array}{c}-0.0198 \\
(0.116)\end{array}$ \\
\hline wlf10 (overall work load) & $\begin{array}{l}0.205^{*} \\
(0.107)\end{array}$ & $\begin{array}{c}0.0912 \\
(0.0867)\end{array}$ & $\begin{array}{c}0.231 * * \\
(0.103)\end{array}$ \\
\hline Constant & $\begin{array}{c}1.314 * * \\
(0.627)\end{array}$ & $\begin{array}{c}3.019 * * * \\
(0.816)\end{array}$ & $\begin{array}{c}2.977 * * * \\
(0.654)\end{array}$ \\
\hline Observations & 74 & 74 & 74 \\
\hline R-squared & 0.400 & 0.201 & 0.226 \\
\hline
\end{tabular}

\section{Discussion}

The influence of workload on employee performance is explained by positive coefficient $(0.28, \mathrm{p}<0.05)$. It shows that an increase on workload will improve the performance of employees. There are three indicators in the workload variable; physical load, mental load, and working time. The ability to complete tasks in accordance with the competencies and feelings of comfort in the workplace is important. Both are important to increase the employee performance although the workload increases. The results of this study are in line with the research of Shah et al. (2011) which concludes that the provision of workload in accordance with the employee's ability and competence can improve performance. The current results are mostly shown by young workers who like challenges. Most of the respondents are less than 26 years old (33.8\%). Kloot and Martin (2000) also stated that a well-managed workload can improve employee performance. Although, the workload can affect physical and psychological conditions, the management of workload can improve employee performance. Employees who like challenges with the burden of 
work are highly eager to improve their performance. On the other hand, their performance will decline if the job is less challenging. This study opposes some other studies (Johari et al., 2018; Munawaroh et al., 2013) which state that workload has no effect on employee performance. Apparently, a sense of comfort with the provision of workload can improve employee performance. A job without workload can reduce employee performance. According to Bruggen (2015) workloads which can improve employee performance refers to moderate workloads. Performance is indirectly influenced by workload through motivation variable. The indirect influence of workload on employee performance is greater than the direct one. Although small, the direct influence of workload affects employee performance. Since, the indirect influence of the workload on the performance through motivation is greater than the direct effect. The level of employee performance is determined by their characteristics. Based on the level of education, about $80 \%$ were highly educated (diploma, undergraduate, and master). Rational employees with high levels of education generally have greater insight than those with lower levels of education. The results of the descriptive analysis show that employees with undergraduate education (S1) have higher motivation to succeed and look for the opportunity to have a self-development. The results are appreciated, and they want to be free to achieve what they love. It concludes that employees with bachelor or master's degree have higher motivation than those with the lower education.

\section{Conclusion}

The purpose of this study was to identify the effect of workload on the performance of bank employees. The analysis agrees that the workload affects the performance of bank employees. An increase in the workload which lets the employees comfortable improve the performance of bank employees. A workload given to the bank employees improves their performance as it suits the ability, does not provide excessive tasks, guarantees comfort, requires performing tasks in accordance with the requirements, and has the right capabilities. Therefore, despite the increase in the workload, the bank employees continue to contribute positively to the employee's performance. This study also shows that workload increasingly improves the performance of bank employees through motivation variables. In fact, employee performance can be influenced by higher burden through work motivation. It means that the indirect effect of workload on performance without motivation variable is greater than the indirect one. Educational level factors have an important role. Employees with undergraduate or higher education background are increasingly motivated to improve their performance. They demand more to have a high achievement than those with low education background. The implication of the current research is useful for the development of human resources. Achievement and motivation are found in many employees who have higher education level. In addition, the provision of workload which is in line with the ability and sense of comfort leads into the improvement of the performance of bank employees. Therefore, the leaders of banks need to consider the education level to recruit the employee. In addition, employee placement based on competence and individual characteristics have impacts on the workload mentality. Thus, the bank leaders are supposed to provide the employee with the appropriate type of work.

This study basically examines the role of workload on employee performance, while there are other work attitudes which still need to be explored further, such as organizational commitment, absenteeism, citizenship behavior (OCB), job satisfaction, and others. Therefore, further research can explore the role of workload on the work attitudes.

\section{References}

Abrivianto, P. (2014). dkk. 2014. Pengaruh Motivasi Kerja dan Komitmen Organisasional terhadap Kinerja Karyawan (Studi pada karyawan bagian HRD PT. Arthawena Sakti Gemilang Malang). Jurnal Administrasi Bisnis, 7(2), 1-9.

Adityawarman, Y., Sanim, B., \& Sinaga, B. M. (2015). Pengaruh Beban Kerja Terhadap Kinerja Karyawan PT. Bank Rakyat Indonesia (Persero Tbk Cabang Krekot. Jurnal Pascasarjana Manajemen dan Bisnis Institut Pertanian Bogor. 
Albasu, J., \& Nyameh, J. (2017). Relevance of stakeholders theory, organizational identity theory and social exchange theory to corporate social responsibility and employees performance in the commercial banks in Nigeria. International Journal of Business, Economics and Management, 4(5), 95-105.

Alsuraykh, N. H., Maior, H. A., Wilson, M. L., Tennent, P., \& Sharples, S. (2018). How stress affects functional near-infrared spectroscopy (fNIRS) measurements of mental workload. Paper presented at the Extended Abstracts of the 2018 CHI Conference on Human Factors in Computing Systems.

Anigbogu, U. E., \& Nduka, E. K. (2014). Stock market performance and economic growth: Evidence from Nigeria employing vector error correction model framework. The Economics and Finance Letters, 1(9), 90-103.

Ali, A., \& Haseeb, M. (2019). Radio frequency identification (RFID) technology as a strategic tool towards higher performance of supply chain operations in textile and apparel industry of Malaysia. Uncertain Supply Chain Management, 7(2), 215-226.

Anita, J., Aziz, N., \& Yunus, M. (2013). Pengaruh penempatan dan beban kerja terhadap motivasi kerja dan dampaknya pada prestasi kerja pegawai dinas tenaga kerja dan mobilitas penduduk aceh. Jurnal Manajemen Pascasarjana Universitas Syiah Kuala, 2(1), 67-77.

Anyanwu, J. O., Okoroji, L. I., Ezewoko, O. F., \& Nwaobilor, C. A. (2016). The impact of training and development on workers performance in Imo State. Global Journal of Social Sciences Studies, 2(2), 51-71.

Astianto, A. (2014). PENGARUH STRES KERJA DAN BEBAN KERJA TERHADAP KINERJA KARYAWAN PERUSAHAAN DAERAH AIR MINUM (PDAM) KOTA SURABAYA.

Avanzi, L., Fraccaroli, F., Castelli, L., Marcionetti, J., Crescentini, A., Balducci, C., \& van Dick, R. (2018). How to mobilize social support against workload and burnout: The role of organizational identification. Teaching and Teacher Education, 69, 154-167.

Baeriswyl, S., Krause, A., Elfering, A., \& Berset, M. (2017). How workload and coworker support relate to emotional exhaustion: The mediating role of sickness presenteeism. International journal of stress management, 24(S1), 52.

Blitar, P., \& Nimah, U. (2015). ANALISIS BEBAN KERJA DAN IMPLIKASINYA TERHADAP KINERJA KARYAWAN DENGAN MOTIVASI SEBAGAI VARIABEL INTERVENING PADA KARYAWAN.

Bruggen, A. (2015). An empirical investigation of the relationship between workload and performance. Management Decision, 53(10), 2377-2389.

Chan, K. W., \& Lam, W. (2011). The trade-off of servicing empowerment on employees' service performance: examining the underlying motivation and workload mechanisms. Journal of the Academy of Marketing Science, 39(4), 609-628.

Chielotam, A. N. (2015). Oguamalam masquerade performance beyond aesthetics. Humanities and Social Sciences Letters, 3(2), 63-71.

Dasgupta, P. R. (2013). Volatility of workload on employee performance and significance of motivation: IT sector. Science Journal of Business and Management, 1(1), 1-7.

Dewi, C. I. A. S., \& Wibawa, I. M. A. (2016). Pengaruh Stres Kerja dan Motivasi Kerja terhadap Kinerja Karyawan pada PT. Bank BPD Bali Cabang Ubud. E-Jurnal Manajemen Universitas Udayana, 5(12).

Duffield, C., Diers, D., O'Brien-Pallas, L., Aisbett, C., Roche, M., King, M., \& Aisbett, K. (2011). Nursing staffing, nursing workload, the work environment and patient outcomes. Applied Nursing Research, 24(4), 244-255.

Fritz, C., \& Sonnentag, S. (2006). Recovery, well-being, and performance-related outcomes: The role of workload and vacation experiences. Journal of Applied Psychology, 91(4), 936.

Gaillard, A. W. (2017). Concentration, stress and performance Performance under stress (pp. 75-92): CRC Press.

Giovanni, T. M., Kojo, C., \& Lengkong, V. P. (2015). Pengaruh Konflik Peran, Konflik Kerja Dan Stres Kerja Terhadap Kinerja Karyawan Pada PT. Air Manado. Jurnal EMBA: Jurnal Riset Ekonomi, Manajemen, Bisnis dan Akuntansi, 3(3). 
Glaser, D. N., Tatum, B. C., Nebeker, D. M., Sorenson, R. C., \& Aiello, J. R. (1999). Workload and social support: Effects on performance and stress. Human Performance, 12(2), 155-176.

Habidin, N. F., Zubir, A. F. M., Conding, J., Jaya, N. A. S. L., \& Hashim, S. (2013). Sustainable manufacturing practices, sustaining lean improvements and sustainable performance in Malaysian automotive industry. World Review of Entrepreneurship, Management and Sustainable Development, 9(4), 444-459.

Harras, H. (2019). The effect of workloads and compensation on work motivation in Sasmita Yaya. Economic, Accounting, Management and Business, 2(1), 21-30.

Haseeb, M., Abidin, I. S. Z., Hye, Q. M. A., \& Hartani, N. H. (2018). The impact of renewable energy on economic well-being of Malaysia: Fresh evidence from auto regressive distributed lag bound testing approach. International Journal of Energy Economics and Policy, 9(1), 269-275.

Haseeb., H. Z., G. Hartani., N.H., Pahi., M.H. Nadeem., H. . (2019). Environmental analysis of the effect of population growth rate on supply chain performance and economic growth of Indonesia. Ekoloji, 28(107).

Ho, T.-S. (2018). Role stress and job burnout of school coaches: Using social support and self-efficiacy as moderators. International Journal of Organizational Innovation, 10(3), 266-284.

Huyghebaert, T., Gillet, N., Beltou, N., Tellier, F., \& Fouquereau, E. (2018). Effects of workload on teachers' functioning: A moderated mediation model including sleeping problems and overcommitment. Stress and Health, 34(5), 601-611.

Jankingthong, K., \& Rurkkhum, S. (2012). Factors affecting job performance: a review of literature. Humanities, Arts and Social Sciences Studies, 12(2), 115-128.

Johari, J., Yean Tan, F., \& Tjik Zulkarnain, Z. I. (2018). Autonomy, workload, work-life balance and job performance among teachers. International Journal of Educational Management, 32(1), 107-120.

Jones Osasuyi, O., \& Mwakipsile, G. (2017). Working Capital Management and Managerial Performance in some Selected Manufacturing Firms in Edo State Nigeria. Journal of Accounting, Business and Finance Research, 1(1), 46-55.

Kahn, S. (2009). Employment of women in the South African National Defence Force 1998-2008. Journal of Public Administration, 44(Special issue 1), 196-208.

Khan, M. M., \& Jabbar, M. (2013). Determinants of employees performance in corporate sector: Case of an emerging market. Business and Management Research, 2(3), 25-32.

Kloot, L., \& Martin, J. (2000). Strategic performance management: A balanced approach to performance management issues in local government. Management Accounting Research, 11(2), 231-251.

Kucukkocaoglu, G., \& Bozkurt, M. A. (2018). Identifying the effects of mergers and acquisitions on Turkish banks performances. Asian Economic and Financial Review, 6(3), 235-244.

Kuranchie-Mensah, E. B., \& Amponsah-Tawiah, K. (2016). Employee motivation and work performance: A comparative study of mining companies in Ghana. Journal of industrial Engineering and Management, 9(2), 255-309.

Le, H. L., Vu, K. T., Du, N. K., \& Tran, M. D. (2018). Impact of working capital management on financial performance: The case of Vietnam. International Journal of Applied Economics, Finance and Accounting, 3(1), 15-20.

Lee, C., \& Way, K. (2010). Individual employment characteristics of hotel employees that play a role in employee satisfaction and work retention. International Journal of Hospitality Management, 29(3), 344-353.

Malarvizhi, C. A., Nahar, R., \& Manzoor, S. R. (2018). The strategic performance of Bangladeshi private commercial banks on post implementation relationship marketing. International Journal of Emerging Trends in Social Sciences, 2(1), 28-33.

Maldonado-Guzman, G., Marin-Aguilar, J., \& Garcia-Vidales, M. (2018). Innovation and performance in Latin-American small family firms. Asian Economic and Financial Review, 8(7), 1008-1020.

Maroofi, F., Ardalan, A. G., \& Tabarzadi, J. (2017). The effect of sales strategies in the financial performance of insurance companies. International Journal of Asian Social Science, 7(2), 150-160.

Maurice, I. U. (2013). Impact of product development and innovation on organisational performance. International Journal of Management and Sustainability, 2(12), 220-230. 
Miller, M. K., Reichert, J., Bornstein, B. H., \& Shulman, G. (2018). Judicial stress: the roles of gender and social support. Psychiatry, Psychology and Law, 25(4), 602-618.

Mosbah, A., Serief, S. R., \& Wahab, K. A. (2017). Performance of family business in Malaysia. International Journal of Social Sciences Perspectives, 1(1), 20-26.

Mowlaei, M. (2017). The impact of AFT on export performance of selected Asian developing countries. Asian Development Policy Review, 5(4), 253-261.

Munawaroh, A., Riantoputra, C. D., \& Marpaung, S. B. (2013). Factors influencing individual performance in an Indonesian government office. The South East Asian Journal of Management, 7(2), 135144.

Namvar, M., Fathian, M., Akhavan, P., \& Reza Gholamian, M. (2010). Exploring the impacts of intellectual property on intellectual capital and company performance: The case of Iranian computer and electronic organizations. Management Decision, 48(5), 676-697.

Ni'mah, U., \& Siswanto, S. (2019). Beban kerja karyawan perbankan, implikasinya terhadap kinerja karyawan melalui variabel motivasi. Journal of Business \& Banking, 6(2), 241-256.

Norman, B. A., Tharmmaphornphilas, W., Needy, K. L., Bidanda, B., \& Warner, R. C. (2002). Worker assignment in cellular manufacturing considering technical and human skills. International Journal of Production Research, 40(6), 1479-1492.

Nugraha, S. J., Banani, A., \& Anggraeni, A. I. (2018). PENGARUH JOB DEMANDS DAN JOB RESOURCES TERHADAP JOB SATISFACTION. Jurnal Ekonomi Bisnis dan Akuntansi (JEBA), 20(3).

Pang, K., \& Lu, C. S. (2018). Organizational motivation, employee job satisfaction and organizational performance: An empirical study of container shipping companies in Taiwan. Maritime Business Review, 3(1), 36-52.

Prasad, K., Vaidya, R., \& Anil Kumar, V. (2018). Association among occupational stress factors and performance at workplace among agricultural research sector employees at hyderabad, India. Pacific Business Review International, 10(7), 27-36.

Purnama, C. (2014). Improved performance through empowerment of small Industry. Journal of Social Economics Research, 1(4), 72-86.

Rabbanee, F. K., Burford, O., \& Ramaseshan, B. (2015). Does employee performance affect customer loyalty in pharmacy services? Journal of Service Theory and Practice, 25(6), 725-743.

Rasheed, M. I., Humayon, A. A., Awan, U., \& Ahmed, A. u. D. (2016). Factors affecting teachers' motivation: an HRM challenge for public sector higher educational institutions of Pakistan (HEIs). International Journal of Educational Management, 30(1), 101-114.

Roster, C. A., \& Ferrari, J. R. (2019). Does work stress lead to office clutter, and how? Mediating influences of emotional exhaustion and indecision. Environment and Behavior, 0013916518823041.

Santhi, N. S., \& Gurunathan, K. B. (2014). Fama-French three factors model in Indian mutual fund market. Asian Journal of Economics and Empirical Research, 1(1), 1-5.

Saranani, F. (2015). Role conflict and stress effect on the performance of employees working in public works department. The International Journal of Engineering and Science, 4(6).

Shah, S. I. H., Khan, A. Z., Bokhari, R. H., \& Raza, M. A. (2011). Exploring the impediments of successful ERP implementation: A case study in a public organization. International Journal of Business and Social Science, 2(22).

Shah, S. S. H., Jabran, A., Ahsan, R., Sidra, W., Wasiq, E., Maira, F., \& Sherazi, S. K. (2012). Impact of stress on employee's performance: a study on teachers of private colleges of Rawalpindi. Asian Journal of Business Management, 4(2), 101-104.

Si, D. M. P. (2015). Effect of cultural organization, leadership and motivation of work on the performance of employees. International Journal of Academic Research in Business and Social Sciences, 5, 158159.

Sitepu, A. T. (2013). Beban kerja dan motivasi pengaruhnya terhadap kinerja karyawan pada PT. Bank Tabungan Negara Tbk Cabang Manado. Jurnal EMBA: Jurnal Riset Ekonomi, Manajemen, Bisnis dan Akuntansi, 1(4). 
Sitepu, I. R., Sestric, R., Ignatia, L., Levin, D., German, J. B., Gillies, L. A., . . . Boundy-Mills, K. L. (2013). Manipulation of culture conditions alters lipid content and fatty acid profiles of a wide variety of known and new oleaginous yeast species. Bioresource technology, 144, 360-369.

Suryanto, T., Haseeb, M., \& Hartani, N. H. (2018). The correlates of developing green supply chain management practices: Firms level analysis in Malaysia. International Journal of Supply Chain Management, 7(5), 316.

Yao, J. C., Shah, M. H., Ito, T., Bohas, C. L., Wolin, E. M., Van Cutsem, E., . . De Vries, E. G. (2011). Everolimus for advanced pancreatic neuroendocrine tumors. New England Journal of Medicine, 364(6), 514-523.

Yurasti, Y., \& Irfandi, R. (2017). PENGARUH BUDAYA ORGANISASI DAN STRES KERJA TERHADAP KINERJA PEGAWAI APARATUR SIPIL NEGARA (ASN) PADA DINAS KESEHATAN KABUPATEN PASAMAN. UNES Journal of Social And Economics Research, 2(1), 106-114.

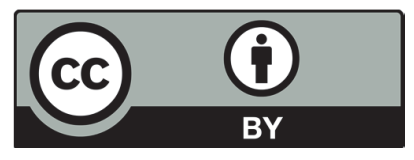

(C) 2019 by the authors; licensee Growing Science, Canada. This is an open access article distributed under the terms and conditions of the Creative Commons Attribution (CCBY) license (http://creativecommons.org/licenses/by/4.0/). 